\title{
Towards Spiritual Entrepreneurship Inecotourism in Southern Africa
}

\author{
Carsten Martin Syvertsen \\ Oestfold University College \\ 1757 Halden, Norway \\ Tel: 47-69-21-5000Ｅ-mail: carsten.syvertsen@hiof.no
}

Received: December 2, 2011

Accepted: December 30, 2011

Published: February 1, 2012

doi:10.5539/ibr.v5n2p94

URL: http://dx.doi.org/10.5539/ibr.v5n2p94

\begin{abstract}
The article sheds light on how ecotourism can be organized in Southern Africa using newer business models as the point of reference. Using chaos theory, the resource based view and dynamic competencies as theoretical basis, the article illustrates how firms within ecotourism can find new ways of organizingas means to become more competitive given a more dynamic and turbulent business environment. We build an innovation model illustrating how it is possible to use radical steps in marketing using spiritual ecotourism in developing countries as the empirical setting. Our methodological position is within the postmodern perspective. It also incorporates elements from the interpretive perspective.
\end{abstract}

Keywords: Southern Africa, Developing economics, Ecotourism, Spirituality, Chaos theory, The resource point of view, Dynamic capabilities

\section{Problem Definition}

We ask: How is it possible to support ecotourism with a focus on spiritual entrepreneurship in developing countries. We use Southern Africa as the empirical setting. In order to address the research question we draw on three complementary theoretical lenses: chaos theory, the resource-based view, and dynamic capabilities.

\section{Ecotourism in Southern Africa}

Africa is the fastest growing region for international tourism, now the world's largest growth industry, with few signs of slowing down. During the last few years, profound shifts have taken place in geopolitics and economic power. The rise in "south- south" trade challenges the dominance of western norms in business and politics, where transparency, governance and ethics are important issues. There should be a great need to innovate and deliver profitable products and services in developing countries. The response from the business world to these challenges may the most critical factor in determining the ability to achieve sustainable and inclusive growth in developing countries.

The economic geography of the post-industrialized world is characterized by fundamental processes of restructuring, an increased mobility of capital and a pursuit for new economic growth activities, particularly in the service sector (Binns and Nel, 2002). Traditional means of investing, conducting marketing and work within political networks have undergone dramatic changes. In recent years, the service sector has become more important worldwide, for example when it comes to consumer preferences, wealth mobility and location mobility (Hall and Page, 1999). One sector that performs well in this context is the tourism industry, which has become one of the critical forces in shaping the economy in many countries (Williams and Shaw,1998). At the same time, there is a debate on how tourism development can support community development and sustainability (Wahab and Pigram, 1997; Elliott et al., 2001).

Tourism has long been considered an effective catalyst of rural socio-economic development and regeneration. Throughout Europe tourism has been widely promoted and relied upon as means of addressing social and economic challenges facing peripheral rural areas, primarily those experiencing a decline in traditional agrarian industries (Cavaco, 1995; Hoggartet al, 1995; Williams and Shaw,1998). Rural tourism development programs have become increasingly evident elsewhere, although not to the same extent as in Europe. In the United States, for example, 30 states have developed tourism politics specifically targeting rural areas, whilst a further 14 have included rural tourism within their overall tourism plans (Luloff et al, 1994).

Southern African countries can lead the way in tourism development in Africa, particularly in ecotourism, the fastest growing sector according to WTO Ecotourism. In recognition of ecotourism's growth potential, particularly in developing countries, the UN Economic and Social Council recently declared 2002 the international year of 
ecotourism. Ecotourism focuses on how to take advantage out of small-scale production. The conservation of protected areas is often highlighted. Ecotourism is viewed as both a conservation and development tool because it can provide conservation benefits and economic benefits.

Ecotourism can involve volunteering, personal growth and learning new ways to living. Such tourism typically involves travel to areas where flora, fauna, and cultural heritages are the main attractions. Ecotourism includes programs that minimize negative aspects of conventional tourism on the environment. It can enhance cultural integrity of local people. Therefore, in addition to evaluating environmental and cultural factors, an integral part of ecotourism generally focuses on improving recycling, energy and water conservation, and the creation of economic opportunities for local communities.

A main part of such tourism development is to focus at spiritual dimensions (Brooks, 2008:4). Safeguarding and transmitting the spirit of places is one of the main objectives of ICOMOS (2008), through a project initiated by UNESCO. ICOMOS (1999) regards "cultural heritage as a dynamic reference point for daily life, social growth and change. It is a major source of cultural capital and an expression of diversity and cultural identity".

\section{Challenges in Ecotourism in Developing Countries with a Focus on Southern Africa}

In order to attract foreign investors, firms in developing countries can lack the superior technology and supporting infrastructure that are necessary to reach global markets (Porter, 1998).Because small-to-medium sized enterprises (SMEs) are common in developing countries, entrepreneurs are plagued with scale constraints on investments in productive assets, including the use of international distribution channels (Sengerberger et al, 1990). A possible way to circumvert such scale and infrastructure limitations isto promote joint action among SMEs through interfirm agreements (Markusen, 1999; Storper, 1997; Tallman et al. 2004).

Ironically, although forging interorganizational collaborative arrangements appears to be critical for SMEs in weak infrastructure settings, it is precisely in those countries that firms also suffer from a host of institutional failures, such as poor legal systems, discretionary governmental policies and inefficient regulation, that hinder the pursuit of joint action and impose high investment uncertainty and exchange hazards (Mesquita, 2003; North, 1990). Suppose, for instance, that SMEs wish to articulate complementary competencies to overcome infrastructure shortcomings. As they invest in resources specific to their joint project and form expectations of outcomes that are difficult to meter ex ante, they may suffer severe contractual hazards (Mesquitaand Lazzarini, 2008).

In many cases the tourist industry will have to relate to situations were land and resource rights are deeply contested. The objective of land reforms in South Africa, to mention one example, is to redress the racially based land dispossessions from the apartheid years, which were characterized by inequitable distribution and ownership over land. Restitution politics aim to restore land and provide other remedies to people dispossessed by radically discriminatory legislation and practice. Policies and procedures are based on the Bill of Rights and the Restitution of Land Rights of 1994 (Department of Land Affairs, 1997). However, implementing land reforms has not been completed as rapidly as many would have wished. Tensions and disputes over land rights are common, going back to the colonial years when chiefs and headmen formed an integrated part of the colonial system (Cousins and Classens, 2003).

European investors can benefit from paying increased attention to distribution ofland and the importance of building local institutions when considering Southern Africa as regions for foreign investments. There are examples where efforts in ecotourism has not worked out as expected. Ecotourism in Wild Coast at the Eastern Cape Province (South Africa)was a failure due to conflicts between villages over the ownership and the use of land. The villages have been engaged in a number of power plays and entered into complex and shifting relationships at different moments of time, ranging from alliances and collaboration at one end of the spectrum to outright hostility and confrontation at the other. Since the beginning of the $90 \mathrm{~s}$ the political terrain has become steadily more complex and turbulent (Cousins and Classsens, 2003).

\section{Methodological Foundations}

We did intensive research on secondarily sources such as public registers and academic articles. We tried to create a meaning out of the data in the research process. We mostly used qualitative methodologies as techniques as these have been associated with descriptive and case study research.

Our methodological position is within the postmodern perspective. It also incorporates elements from the interpretive perspective.An interpretive approach is regarded as suitable for the investigation of complex and poorly understood phenomena (Dixon et al, 2007), since such an approach implies that the researcher's task is to "make sense of local actors' activities" (Soulsby and Clark, 2007, 1426). Thus the important criterion for assessing interpretive data analysis is its ability to provide reasonable insights into the phenomena that demand deeper understandings. Empirical findings illustrate, rather than validate, the theories they reflect (Astley and Zammuto, 1992). 
We assume that meaning is locally created, that sudden change is a part of organizational reality, and that organizational outcomes are often a result of unintended consequences (March, 1994; Weick, 1979). The postmodern view of decision-making is often built on a decentralized framework (Lyotard, 1984; Rosenau, 1992). The methodological perspective of decentralization fits well with the realities in the current economic environment. Economic turbulence coupled with accelerating globalization, continuous improvement of technologies and deregulation of markets has a profound impact on the ability to decentralize.

As the study processed, a similar process to that outlined by Meyer et al (1993), where concepts and research methods were constantly rethought and upgraded following analysis and findings. Similarly, Hinings and Greenwood $(1988,99)$ argued that the researcher has to modify theoretical frameworks during the life of the project. It has been recognized that the conventional research cycle-conceptualization, design, measurement, analysis, and reporting, does not hold well in hyperturbulentmarkets (Chiaburu, 2006). In order to understand organizational phenomena at a more than superficial level, the scholarly literature has called or a more in-depth process research (Langley, 1999).

This study considers change to be a continual process of becoming, rather than a succession of stable states. This viewpoint suggests that social reality is not a steady state, but rather can be regarded as dynamic processes (Beech and Johnson, 2005). Thus, there is a need to observe events and interactions as they unfold over time. This approach suggests that dynamic construction, deconstruction and reconstruction of meaning make sense over time as contextual forces evolve and as organizational restructuring takes place.

\section{The Use of Chaos Theory as a Theoretical Focus}

Ecotourism in Southern Africa is new enough, chaotic enough and in the past unregulated enough so that chaos theory can be used with a certain degree of justification.Chaos theory is the study of complex, nonlinear dynamic systems. Chaos describes a situation where a system is dislodged from its steady state condition by trigging events, where outcomes just as well can lead to harmony as increased tensions. It involves regrouping of elements of a system, for which a new order eventually emerges. The dynamics of systems arise spontaneously from their internal structure. Often small random perturbations are amplified and molded by the feedback structure (Stacey et al, 2000).

The field was pioneered by Lorentz (1963) who studied the dynamics of turbulent flow in fluids. It is when a system is at a state of chaos it is most vulnerable to butterfly effects, where small causes can have large effects on a whole system. Lorentz (1963) also noted that some systems are likely to make "smoothing" adjustments so that "wild fluctuations" in the short term may be partially nullified in the long term through negative feedback mechanisms.

Chaos systems have "life-like" characteristics with an ability of self-organization (Gleick, 1987). A chaotic system can be regarded as an adhesive friction between sand grains, taxed to the limit of their tolerability. It implies a critical point where a single grain dropped on to a pile under maximum stress will cause a sudden phase shift into dramatic chaos manifested in the collapse of a face of the sand pile. Since the critical point can't be determined with exact prediction it can be wise to have plans ready as to how to respond.

Stability is preserved by the properties of redundancy. Redundancy means that the same pattern can be produced in a number of different ways. In order worlds, there is a repetition of efforts, which is unnecessary if one thinks entirely in terms of efficiency. Parts of the process can be damaged or not succeed in producing a repetition of a particular behavior, while others practices will survive. Loose coupling has much the same result. One interaction is not dependent on a very exact way of completion of a number of other interactions (Stacey et al, 2000).

Proponents of chaos theory enthusiastically see signs of it everywhere, pointing to the ubiquity of complex, dynamic systems in the social world and the resemblance between patterns generated by simulated nonlinear systems and real time series of stock exchange or commodity prices. From a theoretical perspective, chaos theory is congruous with the postmodern paradigm, which questions deterministic positivism as it acknowledges the complexity and diversity of experience. While postmodernism has had a profound influence on many areas of social science and the humanities, chaos theory has been neglected by organization theorists until recently (Hassard and Parker, 1993).

Despite its attractions, the application of chaos theory to social sciences is still in its infancy. There are those who think that expectations are too high (Baumol and Benhabib, 1989). Although real life phenomena may resemble the patterns generated by simple nonlinear systems that do not mean that we can easily model and forecast these phenomena. It is almost impossible to take a set of data and determine the system of relationships that generates it (Butler, 1990).

\section{Towards New Organizational Forms in Ecotourism in Southern Africa}

Weare living in times where organization becomes organizing, we speak of the doing of organization (Shane and Venkataran, 2000). Recent research illustrates that the business landscape is neither stable nor predictable (e.g. Hamel, 2000; Muller-Stewans andLechner, 2001;;Leibold et al, 2002).In such a business environment there is a need for organizational flexibility, more create leadership practices and business models that pay increased attention to 
changing customer requirements. Change and uncertainty are constant in the new economic landscape. There are great opportunities in this uncertainty as firms identify and explore business opportunities. Managers are increasingly realizing that the basis of their competitive advantage is found in their knowledge base, and that development and exploitation of knowledge is paramount for the sustainability of such advantages. Hence, better use of existing knowledge and more effective acquisition and assimilation of new knowledge becomes a business imperative.

Scholars and managers have raised serious concern about the extent to which existing approaches to strategy making can help firms in envisaging, conceiving, and realizing more imaginative strategies (Weick, 1989; Hamel, 1996; Chackravarty, 1997; Szulanski and Amin, 2001). It is therefore not a surprise that research increasingly calls for greater attention to imagination in formulating and implementing strategies(Roos and Victor, 1999; Hamel, 2000:3, von Krogh et al, 2000; Szulanski and Amin, 2001: 537).

At the same time we have witnessed a shift in the management literature from the industrial organizational perspective (Mason, 1939; Bain, 1956, 1959, Porter, 1980, 1985) towards the resource based perspective (Wernerfelt, 1984; Barney, 1991;Peteraf, 1993; Amit and Schoemaker, 1993) and finally, towards the dynamic capability perspective(Teecewt al. 1997; Zollo and Winter (2002) and Helfat and Peteraf (2003).

\section{The industrialized organizational perspective (traditional tourism)}

Building on the industrial organization framework strategic management theory and entrepreneurship research suggest that entry barriers are key industry structural characteristics that impact business performance (e.g. Hofer and Schendel, 1978; Porter, 1980). More specifically, IO theory suggests that (1) economics of scale, (2) capital requirements, and (3) product differentiation are the most important entry barriers (Bain, 1956, 1959; Caves, 1972; Hofer, 1975; Shepherd, 1975; Hofer and Schendel, 1978; Porter, 1980; Hay and Morris, 1991; Siegfried and Evans, 1994).

We are of the opinion that the industrialized organizational perspective is related to traditional ways of conducting tourism development, for example by offering package forms of tourism with tour operators playing main roles. This form of tourism mayreach a stage of saturation in Southern Africa due to low entry barriers from other African countries, such as Kenya and Tanzania, and from other continents, for exampleAustralia and Latin America.

In light of an increased sophistication in client needs, natural and spiritual attractions seem to play more important roles in tourism development.Ecotourism can be marketed as a counterpoint to mass, packed tourism. For this reason many destinations are diversifying into ecotourism as traditional sun-and-sand alternatives are not as popular as they once were.

Ecotourism can mitigate the problems of seasonality associated with summer-sun packaged tourism; encourage independent, non-organized tourism; promote cultural tourism, as opposed to climatic attractions of destinations and last, but not least, satisfy the alleged demand for a more environmentally appropriate form of tourism.

\section{The resource based-view (natural resources in ecotourism)}

The resource-based view states that marshaling and uniquely combing a set of complementary and specialized resources and capabilities may lead to value creation. The proposition is that, even in equilibrium, firms may differ in terms of the resources and capabilities they control, and that such asymmetric firms may coexist until some exogenous change or Schumpeterian shock occurs (Wernerfelt, 1984; Barney, 1991; Peteraf, 1993; Amit and Schoemaker, 1993).

The resource-based view of the firm states that the possession of distinctive resources is critical if one wishes to attain competitive advantage (Barney, 1991; Miller and Shamsie, 1996; Peteraf, 1993). Smaller firms may be particularly pressed to reach beyond their boundaries to find and control such key resources (Dyer and Singh, 1998; Stinchcombe, 1965). For instance, SMEs may work together to integrate complementary assets, or even jointly promote investments in common resources (e.g. logistic infrastructure) that would otherwise be prohibitively costly. Essentially, this possibility of joint efforts results from various forms of inter form interdependencies that make the performance of a firm contingent on the performance of other firms in the same industry or market domain.

We regard the resource based-view as related to more traditional ecotourism being offered in the framework of natural resources. We regard natural tourism as being rather passive as it in many cases does not involve much involvement from the tourists. The tourist experience can be limited to seeing, hearing and smelling.

\section{The dynamic capabilities point of view (spiritual dimensions of ecotourism)}

We regard dynamic capabilities point of view as building on more modern ways of approaching tourism development by paying attention to spiritual dimensions of tourism development.

By definition the use of dynamic competencies involves adaptation and change. The dynamic capability approach criticizes both the Porterian industrial economics approach as well as the resource-based approach for neglecting the 
tendency of industry and resource positions to erode over time (Teece et al, 1997; Hamel, 2000; Eisenhardt and Martin, 2000).

While the resource based view literature often has been concerned with questions of value appropriation and sustainability of competitive advantage,, a later extension of the resource based view, the dynamic capabilities approach explores how valuable resource positions are built and acquired over time (Teece et al., 1997). Dynamic capabilities are rooted in a firm's managerial and organizational processes, such as those aimed at coordination, integration and reconfiguration (Teece et al, 1997; Eisenhardt and Martin, 2000). These capabilities enable firms to create and capture Schumpeterian rents (Teece et al, 1997). Examples of such value-creating processes are product development, strategic decision-making, knowledge creation, and capabilities transfers (Eisenhardt and Martin, 2000).

The emergence of spiritual tourism clearly opens up new sources of value creation since relational capabilities and new complementarities among a firm's resources and capabilities can be exploited. We believe that spiritual tourism is more external as it takes place in social settings where the tourist plays an important role in the service delivery.

There are a number of conceptual avenues that can be followed when studying dynamic competencies. We use an approach derived from evolutionary economics. We try to illustrate that the use of dynamic competences is dependent upon routines (Nelson and Winter,1982; Feldman, 2000). We find routines interesting as they can be a source of creating new knowledge. This can be done by using routines in new ways. Such an approach should suit nicely into the realities of ecotourism asentrepreneurial initiatives come from local levels. Business renewal is at the center of the firm's attention, both to create its own internal context for breakthrough performance, and to grow by proactively searching for new markets to serve.

\section{Innovation within Ecotourism in Southern Africa}

Innovation is considered by many scholars and executives to be critical for firms to compete in turbulent business environments (Hitt et al, 1998; Ireland and Hitt, 1999). Hamel (2000) suggests that because the competitive landscape is nonlinear, it requires managers to think in nonlinear ways. Innovation literature is linked to concepts such as tailor making, commercialization and implementation. This means that an idea that is not developed or transformed into a product, or a service, cannot be regarded as an innovation (Fisher, 2001; Garcia and Calantone, 2002; McDermott and O'Connor, 2002).

The types of innovation we interested in studying more closely are technological innovations and marketingbased innovation. Technological innovations can be regarded as links between components, methods and processes leading to new products and services (Afuah, 1998). We link technological innovation to exploitation of knowledge. Marketing based innovations refer to how new knowledge can be embodied in distribution channels, products, applications, and in customer needs (Afuah, 1998). We link marketing innovation to exploration of knowledge.

By combining technological innovations and marketing based innovations it may be possible to analyze what makes tourism firms move from a situation with unclear priorities to a situation with a more clean-cut strategy. This means that we permit careful assessments of non-linear processes. Even if we can explain, ex post, how and why tourism firms moved from archetype $\mathrm{X}$ to archetype $\mathrm{Y}$, or from position $\mathrm{A}$ to position $\mathrm{B}$, it will not be fine-tuned enough to show how, de facto, change takes place (James, 1996, p. 26; Orlikowski, 1996; Feldman, 2000).

In order to succeed in ecotourism firms must be able to tailor make services to well defined market segments through a high degree of crafting, a concept that is related to principles in chaos theory.The use of craftwork, dating back to the early human history, laid the fundaments for civilized societies with a focus on urbanization and economics of scale. The technological developments in the eighteenth century, and particularly those of the nineteenth century, led to more use of machines and a decline in the use of craftwork, relatively speaking. The emergence of the knowledge economy leads to a renaissance of craftwork as novelty has become increasingly important as companies succeed in offering tailor-made solutions to carefully targeted market segments.

As the market for natural ecotourism in Southern Africa matures it will be necessary that spiritual dimensions of service deliveries become more important, moving the attention from a technological focus toward a more marketing oriented one. As the market for natural attractions of ecotourism matures, value adding services related to spiritual dimensions of ecotourism can represent a growth market, according to our reasoning.

In order to analyze how to market spiritual dimensions of ecotourism it can be worthwhile to repeat some findings in the marketing literature. During the 1990s and continuing into the 2000s the issue of value creation for customers started to gain interest in the marketing literature, at the same time as service marketing became more dominating. The prevailing view is that the value for customers is embedded in products that are outputs of firms' manufacturing processes. The view is called value-in-exchange (i.e. Rust et al, 2000). This logic is challenged by an alternative 
viewpoint called value-in-use, where more focus is placed on value-generating processes (Vargo and Lusch, 2004; Gronroos, 2008). According to this view, value is not created by the provider but rather by customers' value-generating processes (Gronroos, 2008).

Customer satisfaction is the hub in a system that connects customer perceptions and emotional responses to subsequent behaviors and business performance. Customer satisfaction is defined as a customer's overall evaluation of an offering's performance (Fornell et al, 1996). Satisfaction includes an offering's ability to provide a pleasurable level of consumption-related fulfillment (Oliver, 1997). Theory suggests that the more experiences one accumulates and integrates into this satisfaction evaluation the more affective and emotional the evaluation becomes (Oliver, 1999).

The classical topic of customer satisfaction/dissatisfaction is still important as it is believed that customer satisfaction has long term benefits, including customer loyalty, and increased profitability (Anderson,1998; Rust and Verhoef. 2005). There is empirical research suggesting that satisfied customers are more loyal, are involved in cross-selling and participate in positive word-of-mouth advertising (e.g. Fornell et al., 1994; Fornell, 1996).

The marketing literature supports a clear links between customer satisfaction on one hand and business performance on the other (Bolton, 1998; Bolton and Lemon, 1999).Research conducted by Mittal and Kamakura (2001) shows a strong albeit nonlinear effect of consumer satisfaction on repurchase behavior for automobiles. With respect to financial performance, customer satisfaction is positively associated with operating margins, return on investment, accounting returns and shareholder value (see Anderson et al, 2004).

\section{What is the Relationship between Innovation and Knowledge Creation?}

We aim to illustrate how the ecotourism industry can become more competitive by focusing on knowledge creation and innovation. Knowledge creation and innovation have a strong and complex relationship, however, seldom examined.We suggest that innovation depends on knowledge creation (Popadiuk and Choo, 2006).

According to our reasoning the resource based view is related to knowledge exploitation while there is a closer link between the dynamic capabilities point of view and the exploration of knowledge, While nature based ecotourism can be linked to exploitation of knowledge, we are of the opinion that spiritual ecotourism to a larger extent is linked to the exploration of knowledge.

While natural attraction in ecotourism can be linked to exploitation of knowledge (technological focus) we are of the opinion that spiritual dimensions of tourism development are more related to the exploration of knowledge (marketing focus). However, this distinction must be used with care as natural tourism and spiritual dimensions of tourism development are not in conflict with each other but can be regarded as two sides of the same coin.

The accumulation of knowledge through learning constitutes a driving force as knowledge acquisition opens new business opportunities (i.e. Penrose, 1959). Tourism institutions in Southern Africa can engage in the exploration of knowledge for the purpose of developing new combinations of knowledge. Exploration involves discovery and experimentation, which can lead to increased productivity through repeated practices.

We believe that the exploration with the use of new processes is a main driver for knowledge creation in ecotourism in Southern Africa. Such a framework can be used as basic for designing path-breaking innovations (Schumpeter, 1947; Nelson and Winter, 1982; Galinic and Rodan, 1998; Fleming, 2001; Nekarand Roberts, 2004).

Insert Figure 1 Here

How to organize ecotourism in the future in Southern Africa can be a question of debate. We suggest that experiencesin the United Kingdom where one pound is paid per visit per day is used as a benchmark and is implemented in all types of tourism in Southern Africa. Such a tax can be welcomed in protected areas where tourism has a potential for hurting the environment. This argument should also be relevant within spiritual ecotourism.

In order for ecotourism projects to succeed governments need to facilitate the creation and growth of private enterprises in labor-intensive sectors of the economy through appropriate politics, infrastructure, and institutions. Reforms to improve the efficiency of capital markets will enable many more local entrepreneurs to create jobs that employ the poor. Lack of good infrastructure results in geographically fragmented markets and firms that are too small to exploit scale economics. Small and medium-sized enterprises need financing options, both when it comes to questions related to debt and equity.

\section{Conclusion, Implications and Future Research}

Given the great degree of complexity and turbulence in the Southern Africa economies, we use chaos theory, the resource based view and dynamic capabilities as our theoretical foundations. We suggest that radical steps in 
marketing and technology are necessary if future growth can take place in both traditional ecotourism and spiritual ecotourism

As change becomes a constant in organizational life, managers in the ecotourism field are struggling to make meaning out of changes. In such contexts sensemaking becomes vital and difficult for managers. According to Weick (1995) sensemaking denotes efforts to interpret and create order for occurrences. Our aim in this article is to illustrate that managers can make sense out of dramatic changes in the tourism industry by focusing more on ecotourism and particularly spiritual ecotourism.

Organizational change spurs reframing, as actors seek to make sense of disparities between their expectations and new experiences (Balogun and Johnson, 2004). According to Bartunek (1984) frames provide a structure of assumptions, rules, and boundaries that guide sensemaking and over time become embedded and taken-for-granted. Shocks and surprises signal that existing frames may no longer apply as is the case where traditional management models make less sense in ecotourism. Reframing, therefore, enables actors to alter meanings attributed to changing situations (Watzalawick et al., 1974). Argyris's (1993) distinction between "single-loop" and "double-loop learning" offers an illustration. Single-loop signifies incremental variations within an existing frame, while double-loop denotes reframing, substantially altering an actor's view and thus enabling dramatic changes in understanding and action. We are of the opinion that the need for double-loop learning should be value for spiritual ecotourism as new management models should be welcome in an emerging growth market.

Ourstudy adds to a growing stream of research on strategy and entrepreneurship dealing with the emergence and competitiveness of clusters, or geographical concentrations of firms (Scmitz and Nadvi, 1999). Although early work on clusters accentuated the benefits that passively accrued to firms from their geographically agglomerating into larger markets, later research of the concept have tended to move away from this emphasis on passive agglomeration economies toward that of active networking among clustered firms (see also Christopherson and Storper, 1986; Markussen, 1999; Mesquita, 2007, Storper, 1997; Tallman et al., 2004). Our study contributes to this later trend in the cluster literature by illustrating that spiritual ecotourism can be a possible economic engine within selected geographical areas. .

We conclude with a call for more research on order to develop a fuller understanding of the interaction between innovation and knowledge creation. Our discussion here suggests that knowledge creation is focused on the generation and application of knowledge that leads to new capabilities of the firm. Innovation is also concerned with how these new capabilities may be turned into products and services that have economic value for markets. Knowledge about markets becomes a critical component of the innovation process, and how firms can proper in an increasingly competitive business environment.

We suggest that entrepreneurship literature is studied more closely as such literature often breaks with traditional business practices. We also believe that future research can benefit from studying more concrete business cases than done in this research, particularly extreme cases as learning effects can be achieved.

\section{References}

Abernathy, W., \& Clark, K. B. (1985), Mapping the winds of creative destruction. Research Policy, 14, 3-22. http://dx.doi.org/10.1016/0048-7333(85)90021-6

Afuah, A. (1998). Innovation Management: Strategies, Implementation, and Profits, Oxford University Press, New York, NY.

Amit, R., \& Schoemaker, P. (1993). Strategic assets and organizational rent. Strategic Management Journal, 14(1), 33-46. http://dx.doi.org/10.1002/smj.4250140105

Anderson, E. W. (1998), Customer satisfaction and word of mouth. Journal of Service Research, 1, 5-17. http://dx.doi.org/10.1177/109467059800100102

Anderson, E. W., Fornell, C., \& Mazvancheryl, S. K. (2004), Customer satisfaction and shareholder value. Journal of Marketing, 68, 172-185. http://dx.doi.org/10.1509/jmkg.68.4.172.42723

Argyris, C. (1993). Knowledge for action: A guide to overcoming barriers to organizational change. Jossey-Bass, San Francisco.

Astley, W. G., \& Zammuto, R. F. (1992). Organization Science, Managers and Language Games. Organization Science, 3(4), 443-460. http://dx.doi.org/10.1287/orsc.3.4.443

Bain, J. S. (1956). Barriers to New Competition. Harvard University Press: Cambridge, MA.

Bain, J. S. (1959). Industrial Organization. Wiley, New York. 
Barney, J. (1991). Firm resources and sustained competitive advantage. Journal of Management, 17(1), 99-120. http://dx.doi.org/10.1177/014920639101700108

Balogun, J., \& Johnson, G. (2004). Organizational restructuring and middle manager sensemaking. Academy of Management Journal, 47, 523-549. http://dx.doi.org/10.2307/20159600

Bartunek, J. M. (1984). Changing interpretive schemes and organizational restructuring: The example of a religious order. Administrative Science Quarterly, 29, 355-372. http://dx.doi.org/10.2307/2393029

Baumol, W., \& Benhabib, J. (1989). Chaos: significance, mechanism, and economic applications. Journal of Economic Perspectives, 3, 77-105.

Beech, N., \& Johnson, P. (2005). Discourses of disputed identities in the practice of strategic change. The mayor, the street-fighter and the insider-out. Journal of Organizational Change Management, 18(1), 31-47. http://dx.doi.org/10.1108/09534810510579832

Binns, T., \& Nel, E. (2002). Tourism as a local development strategy in South Africa. The Geographical Journal, 168(3), 235-247. http://dx.doi.org/10.1111/1475-4959.00051

Bolton, R. N. (1998). A dynamic model of customers' usage of services: usage as an antecedent and consequence of satisfaction. Marketing Science, 17, Winter, 45-65. http://dx.doi.org/10.1287/mksc.17.1.45

Bolton, R. N., \& Lemon, K. N. (1999). A dynamic model of customers' usage as services: usage as an antecedent and consequence of satisfaction. Journal of Marketing Research, 36, 71-86.

Brooks, G. (2008). Developing Guiding Principles for World Heritage as a Sustainable Tourism- A Major UNESCO World Heritage Center Initiative. ICOMOS, Burgerman, NSW/Australia.

Butler, A. (1990). A methodological approach to chaos: Are economists missing the point? Federal Reserve Bank of St. Louis, 72(13), 36-48.

Butler, R. W. (1980). The Concept of a Tourist Area Cycle of Evolution: Implications for Management of Resources. Canadian Geographer, 24(1), 5-12. http://dx.doi.org/10.1111/j.1541-0064.1980.tb00970.x

Cavaoco, C. (1995). Rural tourism: The creation of new tourist spaces In, Montanari, A. \& Williams, A. (eds), European tourism: Regions, spaces and restructuring. Chichester, UK, 129-149.

Caves, R. E. (1972). American Industry: Structure, Conduct, and Performance, 3rd ed., Prentice-Hall: Englewood Cliffs, NJ.

Chakravarrthy, B. (1997). A new strategy framework for coping with turbulence. Sloan Management Review, 38(2), 69-82.

Chandy, R. K., \& Tellis, G. J. (1998), Organizing for radical product innovation: The overlooked role of willingness to cannibalize. Journal of Marketing Research, 35 (4), 119-135. http://dx.doi.org/10.2307/3152166

Chiaburu, D. S. (2006). Managing Organizational change in Transition Economics. Journal of Organizational Change Management, 19(6), 738-746. http://dx.doi.org/10.1108/09534810610708387

Christoperson, S., \& Storper, M. (1986). The city as studio, the world as back lot: The impact of vertical disintegration on the location of the motion picture industry. Environment and Planning D: Society and Space, 4, 305-320. http://dx.doi.org/10.1068/d040305

Cousins, B., \& Classenes, A. (2003). CommercialLand Tenure in South Africa: Livelihood, Rights and Institutions. Development Update, 4 (2), 55-77.

Department of Land Affairs. (1997). White Paper on Land Policy, Department of Land Reforms, Pretoria (South Africa).

Dixon, S. E., Meyer, K. E., \& Day, M. (2007). Exploitation an exploration learning and the development of organizational capabilities: A cross-case analysis of the Russian oil industry. Human Relations, 60 (10), 1493-1523. http://dx.doi.org/10.1177/0018726707083475

Eisenhardt, K. M., \& Martin, J. A. (2000), Dynamic capabilities: what are they?. Strategic Management Journal, 21, special issue, 21(10-11), 1105-1121.

Elliott, G., Mitchell, B., Wiltshire, B., Manan, I. A., \& Wismer, S. (2001), Coastal management: community participation in marine protected area management Wakatobi National Park, Sulawesi, Indonesia. Coastal Management, (29), 295-316. 
Feldman, M. (2000),. Organizational routines as a source of continuous change. Organization Science, 11(6), 611-629. http://dx.doi.org/10.1287/orsc.11.6.611.12529

Fisher, M. (2001). Innovation, knowledge creation and systems of innovation. Annals of Regional Science, 35, 199-216.

Fleming, L. (2001). Recombinant uncertainty in technical search. Management Science, 47, 117-132. http://dx.doi.org/10.1287/mnsc.47.1.117.10671

Fornell, C., \& Cha, J. (1994), Partial least squares, in Bagozzi, R. P. (ed), Advanced Methods of Marketing Research, Blackwell, Cambridge, MA, 52-78.

Fornell, C., Johnson, M. D., Anderson, E. W., Cha, J., \& Bryant, B. E. (1996). The American Customer Satisfaction Index: Nature, Purpose and Findings. Journal of Marketing, 60, Oct., 7-18. http://dx.doi.org/10.2307/1251898

Galinic, D. C., \& Rodan, S. (1998), Resource recombination's in the firm: knowledge structures and the potential of Schumpeterian innovation. Strategic Management Journal, $19, \quad$ 1193-1201. http://dx.doi.org/10.1002/(SICI)1097-0266(1998120)19:12<1193::AID-SMJ5>3.0.CO;2-F

Garcia, R., \& Calantone, R. (2002). A critical look at technological innovation typology and innovativeness terminology: A literature review. Journal of Product Innovation Management, 19(2), 21-35. http://dx.doi.org/10.1016/S0737-6782(01)00132-1

Gleick, J. (1987). Chaos: Making a New Science, Heinermann, London. .

Gronroos, C. (2008). Service logic revisited: who creates value? And who co-creates?, European Business Review, 20(4), 298-314. http://dx.doi.org/10.1108/09555340810886585

Hall. C. M., \& Page, J. (1999). The Geography and Tourism and Recreation: Environment and Place (2nd ed.), Routledge, London.

Hamel, G. (1996). Strategy as revolution. Harvard Business Review, July-Aug.,69-82.

Hamel, G. (2000). Leading the revolution, Harvard Business School Press, Cambridge, MA.

Hassard, J., \& Parker, M. (eds.). (1993). Postmodernism and Organizations, Sage, Thousand Oarks, CA.

Hay, D. A., \& Morris, D. K. (1991). Industrial Economics and Organization: Theory and Evidence, Oxford University Press, New York.

Helfat, C. E.,\& Peteraf, M. (2003). The dynamics resource-based view-capacity life cycles. Strategic Management Journal, 24, 997-1010. http://dx.doi.org/10.1002/smj.332

Henderson, R. M., \& Clark, K. B. (1990). Architectural innovation: the reconfiguration of existing product technologies and the failure of established firm. Administrative Science Quarterly, 35(1), 9-22. http://dx.doi.org/10.2307/2393549

Hinings, C. R., \& Greenwood, R. (1988). The Dynamics of Strategic Change, Basil Blackwell, Oxford (UK).

Hitt, M. A., Ricarti Costa, J. E., \& Nixon, R. D. (1998). The new frontier, In Managing Strategically in an Interconnected World. Hitt, M. A, Ricarti Costa, J. E, \& Nixon, R. D. (eds). Wiley: Chichester, 1-12.

Hofer, C. W. (1975). Toward a contingency theory of business strategy. Academy of Management Journal, 18, 784-810. http://dx.doi.org/10.2307/255379

Hofer, C. W., \& Schendel, D. (1978). Strategy Formulation: Analytical Concepts. West: St. Paul, MN.

Hoggart, K., Buller, H., \& Black, R. (1995). Rural Europe: Identity and change, Arnold: London.

ICOMOS. (1999). International Cultural Tourism Charter, ICOMOS.NSW/Australia.

ICOMOS. (2008). International Cultural Tourism Committee,Developing and Polities for World Heritage and Sustainable Tourism. ICOMOS Science Symposium, Quebeck (Canada).

Ireland, R. D., \& Hitt, M. A. (1999). Achieving and maintaining strategic competitiveness in the 21st century: the role of strategic leadership. Academy of Management Executive, 13(1), 43-57. http://dx.doi.org/10.5465/AME.1999.1567311

James, W. (1996). A Pluralistic Universe, University of Nebraska Press, Lincoln, NE.

Langley, A. (1999). Strategies or Theorizing from Process Data. Academy of Management Review, 24(49), 691-710.

Leibold, M., Probst, G., \& Gibbert, M. (2002). Strategic Management in the Knowledge Economy, John Wiley, \& Sons, Weinheim. 
Lorentz, E. N. (1963). Deterministic non-periodic flow. Journal of the Atmospheric Sciences, 20(2), 130-141. $\mathrm{http}: / / \mathrm{dx}$. doi.org/10.1175/1520-0469(1963)020<0130:DNF>2.0.CO;2

Lyotard, J. F. (1984). The postmodern condition: A report on knowledge, Reading (UK).

Luloff, A., Bridger, J., Graefem, A., Saylor, M., Martin, K., \& Gitelson, R. (1994). Asssessing rural tourism efforts in the United States. Annals of Tourism Research, 2(1), 46-64. http://dx.doi.org/10.1016/0160-7383(94)90004-3

March, J. G. (1994). A primer on decision-making: How decisions happen, The Free Press, New York.

Markusen, A. (1999). Sticky places in slippery space, In Gertler, M. S. (ed.). New industrial geography: Regions, regulations and institutions, Routledge, Florence, KY, 98-124.

Mason, E. S. (1939). Price and production policies of large scale enterprises. American Economic Review, 29, 61-74.

McDermott, C., \& O'Connor, G. C. (2002). Managing radical innovation: An overview of emergent strategy issues. Journal of Product Innovation Management, 19(6), 99-112. http://dx.doi.org/10.1016/S0737-6782(02)00174-1

Mesquita, L. F. (2003). Rationality as the basis for a new institutional environment: Argentina's former presidential candidate Ricardo Lopez Murphy. Academy of Management Executive, 17(3), 44-50.

Mesquita, L. P. (2007). Starting over when the bickering ever ends: Rebuilding aggregate trust among clustered firms through trust facilitators. Academy of Management Review, 32, 72-91. http://dx.doi.org/10.5465/AMR.2007.23463711

Mesquita, L. F., \& Lazzarini, S. G. (2008). Horizontal and vertical relationships in developing economics: implications for SMEs' access to global markets. Academy of Management Journal, 51(2), 359-380. http://dx.doi.org/10.5465/AMJ.2008.31767280

Meyer, A. D., Goes, J. B., \& Brooks, G. R. (1993). Organizations Reacting to Hyperturbulence, in Huber, C. P., \& Glink, W. H. (eds.). Organizational Change and Redesign: Ideas and Insights for Improving Performance, Oxford University Press, Oxford.

Mueller-Stewens, G., \& Lechner, C. (2001). Strategischers Management: Wiestrategische Initiativenwirksam warden, Schaeffer-PoeschlVerlag, Skuttgart (Germany).

Nelson, R. R., \& Winter, S. G. (1982). An Evolutionary Theory of Economic Change, Belknap Press, Cambridge, MA. .

Nerkar, A., \& Roberts, P. W.(2004). Technological and product-market experience and the success of new product introductions in the pharmaceutical industry. Strategic Management Journal, 25, 779-799. http://dx.doi.org/10.1002/smj.417

North, D. C. (1990). Institutions, institutional change, and economic performance, Cambridge University Press, New York.

Orlikowski, W. J. (1996). Improvising organizational transformation over time: a situated change perspective. Information Systems Research, 7, 63-92. http://dx.doi.org/10.1287/isre.7.1.63

Penrose, E. T. (1959). The Theory of the Growth of the Firm, Basil Blackwell, London.

Peteraf, M. A. (1993). The cornerstone of competitive advantage: A resource-based view. Strategic Management Journal, 14(3). 179-191. http://dx.doi.org/10.1002/smj.4250140303

Popadiuk, S., \& Choo, C. W. (2006). Innovation and knowledge creation: how are these concepts related? International Journal of Information Management, 26, 302-312. http://dx.doi.org/10.1016/j.ijinfomgt.2006.03.011

Porter, M. E. (1980). Competitive strategy, The Free Press. New York, NY.

Porter, M. E. (1985). Competitive advantage, The Free Press, New York, NY.

Porter, M. E. (1998). Clusters and competition: New agendas for companies, governments, and institutions, In Porter, M. E. (ed.). On competiveness, Harvard Business School Press, Boston, 197-288.

Roos, J., \& Victor, B. (1999). Towards a new model of strategy-making as serious play. European Management Journal, 17(4). 348-355. http://dx.doi.org/10.1016/S0263-2373(99)00015-8

Rosenau, P. M. (1992). Postmodernism and the social sciences: Insights, inroads, and intrusions, Princeton, NJ.

Rust, R. T., \& Verhoef, P. C. (2005). Optimizing the marketing interventions mix in intermediate-term CRM. Marketing Science, 24, 477-489. http://dx.doi.org/10.1287/mksc.1040.0107

Schumpeter, J. (1947). The creative response in economic history. Journal of Economic History, 7, 149-159. 
Schmitz, H., \& Nadvi, K. (1999). Clustering and industrialization: Introduction. World Development, 27, 1503-1514. http://dx.doi.org/10.1016/S0305-750X(99)00072-8

Sengenberger, W., Loveman, G. W., \& Piore, M. J. (1990). The reemerge of small enterprises: Industrial restructuring in industrialized countries. IlO, Geneva,(Switzerland).

Shane, S., \& Venkataraman, S. (2000). The promise of entrepreneurship as a field of research. Academy of Management Review, 25, 217-226.

Shephered, W. G. (1975). The Treatment of Market Power: Antitrust, Regulation, and Public Enterprise. Columbia University Press, New York.

Soulsby, A., \& Clark, E. (2007). Organization Theory and the Post-socialist Transformation: Contributions to Organizational Knowledge. Human Relations, 60 (10). 1419-1442. http://dx.doi.org/10.1177/0018726707083470

Stiegfrid, J. J., \& Evans, L. B. (1994). Empirical studies of entry and exit: a survey of the evidence, Review of Industrial Organization, 2, 121-155. http://dx.doi.org/10.1007/BF01035654

Stacey, R. D., Griffen, J. D., \& Shaw, P. (2000). Complexity and Management: Fad or Radical Challenge to Systems Thinking? Routledge, London.

Stiegfrid, J. J.\& Evans, L. B. (1994). Empirical studies of entry and exit: a survey of the evidence, Review of Industrial Organization, 2, 121-55. http://dx.doi.org/10.1007/BF01035654

Stinchcombe, A. L. (1965). Social Structure and Organizations, In March, J. G. (ed.). Handbook of organization, RandMcNally, Chicago, 142-193.

Storper, M. (1997). The regional world: Territorial development in a global economy, Guildford Press, New York.

Szulanski, G., \& Amin, K. (2001). Learning to make strategy: balancing discipline and imagination. Long Range Planning, 34, 537-556. http://dx.doi.org/10.1016/S0024-6301(01)00073-5

Teece, D. J, Pisano,G., \& Shuen, A. (1997). Dynamic capabilities and strategic management, Strategic Management Journal, 18(7). 509-533. http://dx.doi.org/10.1002/(SICI)1097-0266(199708)18:7<509::AID-SMJ882>3.0.CO;2-Z

Tushman, M. L., Anderson, P. C., \& O’Reily, T. (1997). Technological cycles, innovation streams and ambidextrous organizations: organizational renewal through innovation streams and strategic change, InTushman, M. L. \& Anderson P. (eds). Managing strategic innovation and change: A collection of readings, Oxford University Press, New York.

Tallman, S., Jenins, M., Henry, N., \& Pinch, S. (2004). Knowledge, clusters, and competitive advantage. Academy of Management Review, 29, 231-258.

Vargo, S. L., \& Lusch, R. F. (2004). Evolving to a new dominant logic for marketing. Journal of Marketing, 68, 1-17. http://dx.doi.org/10.1509/jmkg.68.1.1.24036

Von Krogh, G., Ichijo, K., \& Nonaka, I. (2000). Enabling knowledge creation, Oxford University Press, Oxford (UK). http://dx.doi.org/10.1093/acprof:oso/9780195126167.001.0001

Wahab, S., \& Pigram, D. (1997). Tourism development and growth: the challenge of sustainability, Routledge, London. 
Knowledge creation

\begin{tabular}{|l|l|l|}
\hline $\begin{array}{l}\text { Innovation } \\
\text { t technology and marketing) }\end{array}$ & $\begin{array}{l}\text { Exploitation of knowledge } \\
\text { Traditional ecotourism (nature) } \\
\text { Use of technology/ (the resource based } \\
\text { view }\end{array}$ & $\begin{array}{l}\text { Exploration of knowledge } \\
\text { Newer forms of ecotourism (spiritual } \\
\text { dimensions) } \\
\text { Use of marketing/ (dynamic competencies }\end{array}$ \\
\hline New processes & $\begin{array}{l}\text { Regular innovations (A) } \\
\text { Revolutionary innovations (A) } \\
\text { Major process innovations (B) } \\
\text { Technological innovations (D) }\end{array}$ \\
\hline Existing processes & $\begin{array}{l}\text { Niche innovations (A) } \\
\text { Modular innovations (B) }\end{array}$ & $\begin{array}{l}\text { Radical innovations (B) } \\
\text { Process/product and service innovations (C) } \\
\text { Market breakthroughs (D) }\end{array}$ \\
\hline
\end{tabular}

Figure 1. Innovation and Knowledge Creation in Ecotourism in Southern Africa
(A) Abernathy and Clark (1985)
(B) Henderson and Clark (1990)
(C) Tushman et al (1997)
(D) Chandy and Tellis (1998) 